\title{
IMPLICATION IN THE ARTISTIC TEXT
}

\author{
Madaminova Muhabbat Sotvoldievna \\ Basic doctorate (PhD) of Andizhan State University, Andizhan, Republic of Uzbekistan
}

Article DOI: https://doi.org/10.36713/epra4292

\begin{abstract}
This article examines the specific features of the literary text, its meaning. Also, the complex semantic structure of implicitism expressed in speech, is expressed through various means. Therefore, in the research showed that linguistic ability to comprehend and also the reserve of general knowledge as well.
\end{abstract}

KEY WORDS: Literary text, language units, implicit, repression, artistic skill, explicit, anthropocentric.

\section{INTRODUCTION}

It is natural that the peculiarities of a literary text make it effective in the study of its hidden meanings. Along with the linguistic ability to comprehend and comprehend them, the reserve of general knowledge in the mind is also activated. M. Hakimov uses the term "general" to describe the concept of implication and notes that it covers all hidden meanings, but although no research has been conducted in the Uzbek language, the theoretical sources of classical literature are very rich in factual material in this area [1]. Speech manifests itself in the form of a syntactic device in the process of information exchange as the main means of communication between people - communicative speech integrity. The virtual base of a particular language is actualized in spoken sentences. As a result of the global development of linguistics over the last hundred years, a multifaceted paradigmatic field of study of the position of speech as a syntactic whole with layers of expression, content and meaning was formed, and on this basis the possibilities of textual structure began to be explored.

\section{RESEARCH METHODS}

Researcher N.A. Panina was one of the first to address the issue of implication (1979): "Implicitism is the ability to indirectly understand the meaning of a sentence and to obtain additional information from it". Therefore, I.V. Arnold admits that in implication "additional meanings appear in the micro context and are not directly expressed by language units".

E.V. Ermakova in the context of syntactic semantics initially the main characteristics of implicit (G.G. Pocheptsov, I.P. Susov, L.V. Lisochenko, Yu.S. Martemyanov, N.D. Arutyunova, V.V. Bogdanov) if investigated and the issue of implicitity in the direct literary text is relatively little studied (Dolinin 1983, Bogdasaryan 1983, Nikitin 1988, Sitdikova 1985, Molchanova 1988, Bezugla 2007, Ermakova 2007, 2008, 2009, Bertuccelli-Papi 2000) [2].

\section{RESULTS AND DISCUSSIONS}

In Uzbek linguistics, the views on the external and internal meanings of the work of art have long existed in the classical literature, but the research on implicitism in modern literary texts is still in its infancy. The complex semantic structure of implicitism expressed in speech, expressed through various means, is one of the most complex issues of interest to many today. The implicit meanings expressed implicitly also depend on the writer's artistic skill, the extent to which he has mastered the richness of language, and his ability to make skilful use of the methodological possibilities of language units. This leads to the conclusion that artistic texts can be a broad field for defining the means of expressing implication. The extent to which the author intends to provide implicit information 


\section{EPRA International Journal of Research and Development (IJRD)

through his work, the understanding of the hidden statement of the expressed content depends on the level of the addressee's thinking ability and perception of the world.

The concept of implicitism is useful in the analysis of many symbolic-figurative prose works that have appeared in Uzbek prose in recent years as "an element that is not directly expressed in linguistic means, understood by the listener due to the interaction of the conditions of speech structure and explicit meaning" [3]. For example, the story of Nazar Eshankul "The man led by a monkey", Uncle Murad's "Fields left by my father", Murad Muhammad's novel "Lolazor", Khurshid Dustmuhammad's novel "Market" and many others.

According to the anthropocentric principle, the speech situation in a literary text acquires a polyphonic essence: "the author is the creator of the work of art; moving person; the reader is the "creator" of the work of art".

Approached from this point of view, if the addressee-addressee dialogue takes place in a simple discursive text, the meaning of the literary text becomes twofold complicated. The author's subjective attitude is also understood in the process of "moving persons", for example, the process of discursive communication between the characters.

- Менга қара, Қурбоной.

Қурбоной хола қаддини ростлади. Комиссар сут бидонини қор устига қўйиб, алланечук қунишиб турар, захил юзи ўйчан эди.

- Ростингни айт! - деди кинояли илжайиб. - Жойнамоз устида хар куни қарғасанг керак мени? Ота-онанг учун, ўзинг учун... Фақат тўғрисини айт!

- Ўзимга нима қипти? - дедu Қурбоной хола дили оғриб.

- Хэх! - Комиссар калтакесакдек чирқиллаб кулди. - Ўзинг бўлмаса ота-онанд учун..

- Мен хеч кимни қарғамийман, деди Курбоной хола ишонч билан. Қуръонда битилган: Аллох хар нарсани кўргувчидир. Тангрим хаммасини кўриб турибди.

Комиссар бирпас гезариб турди-да, бидон бандидан кўтарди. Индамай нари кетдu. [Ў.Хошимов “Тушда кечган умрлар", 74-бет.]

"Look at me, Kurbanoy".

Aunt Kurbanoy straightened up. The Commissar placed the milk jug on the snow, and sighed, his ugly face thoughtful.
"Tell the truth!" He said with a sarcastic smile. "You must curse me every day on the couch?" For your parents, for yourself ... Just tell the truth!

"What happened to me?" Said Aunt Kurbanoy, her heart aching.

- Xex! The Commissar laughed like a lizard. "If not for you, for your parents ..."

"I am not cursing anyone," said Aunt Kurbanoy confidently. - It is written in the Kuran: Allah (God) is All-Seeing. God sees it all.

The Commissar walked for a moment and lifted the canister. He walked away in silence. [U. Hoshimov, "Lives in a Dream" p. 74]

In this passage, the implicit meaning of the text emerges through allusion. Allusion (Latin allusio - sign, joke) is a stylistic method based on the reference to a real political, domestic, historical or literary fact that is considered familiar to all. In essence, it comes close to the art of talmeh, which is widely used in Eastern classical poetry. The difference is that while talmeh refers to more popular historical and artistic facts, in allusion the artist may also refer to political, domestic, or artistic facts of his time. That is, in the allusion, the scope of the reference object is wider [5, p.28].

While Kurbanoy's phrase "God sees everything" expresses the opposition "God punishes", this short discursive dialogue at the end of the work is a series of years of colonial years in the former Soviet Union, spiritual pressures, horrors of repression, generations brought up under the influence of the existing social environment. The painful points of the nation, such as the tragedy, are the intersections in the lives of the characters - the Commissar's view of the Victims' Family as a class enemy, the murder of his parents, the flour a young orphan, that it is responsible for many problems in life, and the lives of many people as being typical of the social life of the Commissioner at the end of the chorus who Kurbanoy witness is happening with their own eyes as expressive characters, speech bubble processes through the prism of the author. Interestingly, these implicit meanings emerge not through the author's speech, but through the explicit content in the text of the work and the speech of the characters.

\section{CONCLUSION}

Thus, the artist expresses his ideas and thoughts about the environment in the literary text from the point of view of his own point of view, incorporating them into the reality described in his work. That is why the addressee (reader) perceives the literary text as a real reflection of the being, is affected. 


\section{REFERENCES}

1. Ermakova E.V. Implicitness in a literary text (based on the material of Russian-language and English-language prose of psychological and fantastic realism) -Dissertation for the degree of doctor of philological sciences, Saratov-2010 (In Russian).

2. Shamaxmudova A. Concepts of indirect and implicit in modern linguistics // Foreign philology. -№1, 2017.

3. Yusupov O. Linguocognitive features of literary text // TSPU Scientific Information Scientific-theoretical journal № 2 (11) 2017.

4. Kuronov D, Mamazhonov Z, Sheralieva $M$. Dictionary of Literary Criticism // Under the general editorship of D. Kuronov. Tashkent: Akademnashr, 2010.

5. Hakimov M. Fundamentals of Uzbek pragmalinguistics -T., Akademnashr, 2013. 